\title{
THE SUN, THE MOON AND FIRMAMENT IN CHUKCHI MYTHOLOGY AND ON THE RELATIONS OF CELESTIAL BODIES AND SACRIFICE
}

\section{Ülo Siimets}

\begin{abstract}
This article gives a brief overview of the most common Chukchi myths, notions and beliefs related to celestial bodies at the end of the 19th and during the 20 th century. The firmament of Chukchi world view is connected with their main source of subsistence - reindeer herding. Chukchis are one of the very few Siberian indigenous people who have preserved their religion. Similarly to many other nations, the peoples of the Far North as well as Chukchis personify the Sun, the Moon and stars. The article also points out the similarities between Chukchi notions and these of other peoples. Till now Chukchi reindeer herders seek the supposed help or influence of a constellation or planet when making important sacrifices (for example, offering sacrifices in a full moon). According to the Chukchi religion the most important celestial character is the Sun. It is spoken of as an individual being (vałrg bn). In addition to the Sun, the Creator, Dawn, Zenith, Midday and the North Star also belong to the ranks of special (superior) beings. The Moon in Chukchi mythology is a man and a being in one person. It is as the ketlja (evil spirit) of the Sun. Chukchi myths about several stars (such as the North Star and Betelgeuse) resemble to a great extent these of other peoples.
\end{abstract}

Keywords: astral mythology, the Moon, sacrifices, reindeer herding, the Sun, celestial bodies, Chukchi religion, constellations.

The interdependence of the Earth and celestial as well as weather phenomena has a special meaning for mankind for it is the co-existence of the Sun and Moon, day and night, wind, rainfall and soil that creates life and warmth and provides the daily bread. Over all things there is only one heaven. Stars emerge from the dark sky and their innumerability makes the thinking man answer questions about the essence and origin of life and its purpose. People already meditated on such questions in foregone times and will do the same in the future. In every era there have been attempts to give answers to these questions according to the level of knowledge.

At different times different divinities have governed the world, yet in the entire course of human history the Sun has been considered 
the very source of everything. The symbols of the Earth complement those of the sky and represent the Great Mother (Mother Earth) who is fertilised by rain and gives birth to plants that give food to other living beings. The mythological theme of Mother Earth stretches back to thousands of years. There have been discovered clay figures of big-breasted women representing their reproductive and feeding role dating back to over 20,000 years B.C. According to beliefs seas, lakes and rivers are a part of the bountiful gifts of the universe, sharing feminine and nourishing qualities with the earth. For the sky is the residence of the Sun, Moon and stars, it has always been linked to creative powers and creative divinities.

This article gives a brief overview of the most common Chukchi myths, notions and beliefs related to celestial bodies at the end of the 19th and beginning of the 20th century. Whenever similarities with the myths of other peoples have been spotted, these are outlined in the article. The article is based on the observations of the Chukchi explorer Vladimir Bogoraz-Tan, the book Eesti taevas. Uskumusi ja tõlgendusi (Kuperjanov 2003) by Andres Kuperjanov and the author's notes taken in 1971 when he lived in the Chukchi land. If any connections with a celestial body have been discovered, interesting facts from the book Mythologies of the World (McKenzie $\&$ Prime \& George \& Dunning 2001) are presented for comparison.

Similarly to many other nations, the peoples of the Far North as well as the Chukchi personify the Sun, the Moon and stars. They are alive, but of a somewhat different origin than other beings. However, it is still them people turn to in prayers and spells. Even in the recent past very many peoples brought sacrifices in their honour or still do.

While herding reindeer with the Chukchi I noticed that, firstly, all their principal sacrificial activities are related to reindeer. It is understandable for their entire life depends on the well-being of the reindeer herd. Secondly, the supposed help or influence of a constellation or planet was sought when making important sacrifices (for example, offering sacrifices in a full moon). I have seen such sacrificial rituals myself and heard Chukchis explain them. When bringing sacrifices, the supposed influence of the Moon, North Star or some other celestial body is used. 


\section{THE SUN}

In numerous cultures around the world the Sun, besides being the embodiment of light and warmth, is seen as masculine. The everyday rising and setting of the Sun represents death and rebirth. The Sun warms the earth and ripens grain. When speaking about the Sun or sun-gods, the first thought that springs to mind is certainly that of the Egyptian solar deity Ra. Each morning he starts his journey across the sky, defeating the chaos of darkness and destroying evil. It is common knowledge from history lessons that the Egyptian pharaoh Amenhotep IV declared that Aton (the Sun) is the only god. In ancient Egypt the sun-god Ra had three aspects: in the morning the dung beetle Khepri, in daytime the falcon-headed Ra and in the evening man, or ram-headed Atum, who represented the setting sun. Every morning the Sun had to fight the serpent god Apep, the deification of chaos (McKenzie \& Prime \& George \& Dunning 2001: 34).

The Sumerian sun-god Utu was the enemy of darkness and evil, and chased away diseases with the healing power in his wings. He was also the god of justice. In later times he was called Shamash which in the Akkadian language means "sun" (McKenzie \& Prime \& George \& Dunning 2001: 24).

Lug, the god of light and the Sun, was one the few Celtic gods who was worshipped from Ireland to Spain. In translation his name means "bright." Lug was a warrior, magician and the master of all crafts. In Celtic mythology fire symbolised the Sun. Celtic people celebrated the succession of seasons with four great festivals. Of these the most important ones were samhain and beltine with which the arrival of winter and summer, respectively, was celebrated. The other two - imbolc and lugnasad - were held in February and August. Scandinavians also had similar festivals of which the eminent one was the celebration of the start of winter, lasting for several days. It was called the celebration of winter nights. Antique authors write about Celtic celebrations, especially fertility rites and human sacrifices during samhain. People were drowned in honour of the god Toutatis and burnt in baskets to propitiate the god called Taranis (McKenzie \& Prime \& George \& Dunning 2001: 69, 72; see also Ó hÓgáin 2004). 
The most monstrous sacrifices to the Sun were brought in the Americas. The Incas and Aztecs conducted especially bloody sacrificial rites. The central form of worship in the Incan Empire was the sun cult. The heart of the religion was located in the Coricancha temple in Cusco. The temple included six rooms of which one was dedicated to Inti, the sun-god, who was considered to be the divine male ancestor of Incan genealogy. In the room, which was lavishly covered with gold, there was a statue of Inti. The main celebration held in his honour was Inti Raymi. The second room was decorated with silver and dedicated to the Moon. The moon-god was called Killa and she was believed to be the divine female ancestor of the Incas. The third room was for the thunder-god Illapa and the fourth for the creator-god Viracocha.

When a new Incan king was enthroned, all four provinces of Tawantinsuyu (the Four Lands Together) had to send offerings to the capital. These included llamas, alpacas, fabrics, precious metals as well as children. The Incas received the offerings in Cusco's town square. Children marched twice around the statues of the Creator, Sun, Moon and Thunder. Then the Incas called the priests of the four provinces and let them divide the offerings into four according to the four regions of the Empire. Children were told to leave town after which they travelled to huacas 'sacred places' in the mountains. There they were sacrificed. Their hearts were torn out and the surface of the huaca was smeared with blood.

The most important deeds of Aztec creation-gods are connected with the creation of the Sun. It was believed that in order for the Sun to continue its celestial journey which would also mean preserving the unity of the Aztec Empire, the Sun needed to be continually fed with human blood. Thus the cults of Tonatiuh (the Sun) and Huitzilopochtl (wars of the Sun) were the cornerstones of the Aztec Empire. Providing sacrifices was the task of warriors. When there were not enough captives or volunteers, the warriors themselves had to sacrifice their lives to gods. Obviously the Sun's hunger for blood was infinite. In the great temple children were also sacrificed. Every year at sacrificial ceremonies around 20,000 people were killed. The Sun occupied a central place in the Aztec calendar. A year consisted of 18 months (McKenzie \& Prime \& George \& Dunning 2001: 129-136). Yet all explorers are not unanimous as to 
whether human sacrifices were brought, for example, Tarmo Kulmar has voiced different opinions (2004).

The Greek sun-god Apollo was the defeater of darkness who in pictures and mosaics was depicted as a man whose head is surrounded by flames.

Alchemists in medieval Europe thought that the Sun with its internal fire, being also one of the elements, is present in all matter. Therefore the Sun is among the symbols of the Freemasons.

According to Chukchi religion the most important celestial character is the Sun. Yet it is not as blood-thirsty as American sun-gods. According to Vladimir Bogoraz-Tan the Chukchis describe the Sun as an individual being (vaъrgъn). In addition to the Sun, the Creator, Dawn, Zenith, Midday and the North Star also belong to the ranks of special (superior) beings.

The Sun is depicted as a man in shining clothes (in copper or gold) who travels around the sky by a dogsled or reindeer team. The reindeer have golden or copper horns. He extended one of his rays to the Earth, married an earthborn girl and pulled her up to the sky with the ray. Every evening the Sun returns to his wife. The wife is called Kavra-yna 'Woman Who Goes Round' (Bogoraz-Tan 1939: 25). It can be gathered from the name that in Chukchi mythology the Sun and his wife live as nomadic people - in a portable house. Chukchi cattle herders are constantly on the move and their lodging with them.

The god gave some of his reindeer to men. It is white reindeer who descend from the sun-herd. Spotted, grey and brown reindeer originate from below the ground, Oviri-nutenut 'the land delivering furs'. This land can be found where the earth and sky meet. At that place there is a large hole in the ground from which reindeer escaping from wolves run out.

\section{THE MOON}

The Moon is the symbol of death and rebirth due to its monthly wax and wane. The Moon dominates waters, making them ebb and flow. 
The Sumerian moon-goddess is called Nanna. In the city of Ur there was huge ziggurat at the summit of which was located the goddess' temple. City-dwellers brought gifts to Nanna, placing them on sacrificial tables of stone. They also presented little figurines depicting praying persons which were set next to Nanna's statue so as to constantly pray for the givers. Animals were also sacrificed in temples. Governors regularly organised ceremonies at Nanna's altar to dispel evil and grant a long life for themselves. Only the high priest was allowed to enter the holy of holies - Nanna's abode. Later Nanna was called by the Akkadian name Sin. It was symbolised by the new moon (McKenzie \& Prime \& George \& Dunning 2001: 25-27).

In Egyptian mythology the moon-god Thot was the messenger, deputy and vizier of the sun-god Ra. According to myth Thot serves as a judge in the quarrel for the throne between Horus and Set. Set cajoled Horus to enter his house and attempted to have sexual intercourse with him in order to prove the effeminacy of Horus. Horus manages to catch Set's seed. Isis, the mother of Horus, took some of her son's seed and sprinkled it on lettuce, the favourite food of Set, which the latter then eats. When Set appeared in front of the council of gods to boast with his victory and demand kingship, the judge called the seeds of Set and Horus. Set's seed answered from the depth of the sea, but Horus' seed turned into a moon disc that grew out of Set's head. Thot took the moon and put it on his head as a divine symbol.

Gods could be called to temples by means of prayers and rituals, using figures or sacred animals. The sacred animals of the moongod were ibises whose mummified bodies have been found in many tombs. Thot was pictured as a baboon-faced man (McKenzie \& Prime \& George \& Dunning 2001: 32, 34, 38-39).

According to Incan myths the Moon (Killa) was at first brighter than the Sun. The Sun grew jealous and threw ashes on Moon's face so that its brightness dimmed, resembling the Moon of today (McKenzie \& Prime \& George \& Dunning 2001: 129).

In Chukchi mythology the Moon is a man and a being in one person. In the Chukchi worldview it has the opposite position to the Sun. It is as the ketlja (evil spirit) of the Sun. Shamans and other conjurers turn to the Moon. The Moon helps to carry out wicked schemes: to 
cast curses or spells on others. The Moon should not be looked upon for too long a time for then one goes mad or is taken from the Earth to other spheres, for example, to the Moon. The Moon has a chaad 'a lasso', 'lariat' which he uses to catch people and pull them to him. He has already caught a boy or a girl or both of them with that and dragged them to his abode on the moon. Because the Moon owns a chaad, pieces of strap are sacrificed to him at Chukchi festivities (Bogoraz-Tan 1939: 22-23).

The myth that a human being inhabits the Moon is widespread in Estonia as well as in other Nordic countries (Kuperjanov 2003: 69).

Using the Moon to strengthen the influence of spells is very common in Chukchi culture. In a legend an old shaman Jelöpa turns to the Moon for help. The shaman did not have enough power to punish his enemy who owned a reindeer flock and wanted to drive the shaman away for he was too old. In that case the shaman would have frozen to death in the tundra or just died of hunger. Now the shaman has not been left any other choice than to seek the death of his enemy by using spells. Next follows an extract of the story.

To carry out the ritual, the shaman needed the help of the full moon. He could not do anything else but wait and secretly damn the enemy. Finally it was the time of the full moon. The sky was clear. The stars twinkled and the moon resembled a large yellow disc. The shaman had started with rituals in good time in the sacred or "dark" yaranga. The rumble of his bubin echoed fiercely over the tundra which also witnessed his shrieks and screams. Usually others took part in his rituals, but this time he carried it out completely alone. People in nearby yarangas could not get any sleep. At times his screams turned into screeching, at times deep mumbling was heard. The same could be said about the beat of the bubin - the sound came in waves. At times a quick and highpitched sound was heard, at times dark thumps.

At midnight the drum fell silent. One of the herdsmen, who did not dare to go out before, left his yaranga to relieve himself. Having finished with that, he heard voices over the shaman's yaranga. He peeked from behind his yaranga and saw to his surprise that Jelöpa was walking on all fours. He was stark naked. The shaman was wearing only a hat made of the fur from animal scalps. Jelöpa crawled to the tundra directly toward the moon. 
The herdsman could not understand all that was said, but the overall meaning of the words was something like:

"Oh Moon, Moon. You, who govern the night.

You who can break the darkness, help me. You see how humbly I am crawling before you.

I have no secrets from you, I present my body to you completely. Help me.

Help me to defeat my enemy. He has abased me. He has derided me in front of others. Have mercy on me. I have always brought you sacrifices and I will continue to do so, if you help me.

Help me to soothe my anger. Make my enemy die." (For a longer version, see Siimets 2003: 231-245.)

A couple of weeks after the ritual was carried out, the enemy died and the shaman was again the most important person among reindeer herders.

The Moon was also personified in earlier Estonian beliefs. For instance, he was one of the suitors of the Star Bride. In addition, the custom that when seeing a new moon for the first time it should be greeted and asked for money, wealth and the fulfilment of wishes also gives witness to the belief. For the latter end it should be enough to jingle coins in the pocket upon seeing a new moon or show money to the moon. As a rule, the moon was addressed in spells. Estonian moon spells have been recorded from ancient times to the present day. Differently from many spells that are forgotten or known only by special persons, moon spells are still used when healing (Kuperjanov 2003: 74).

The situation among the Chukchi people is similar. Younger people do not know the meaning of spells any more or do not want to talk about that. When I asked why they carry out certain rituals or say spells, they answered: for things to go better. Many shamanic healing rituals took place during the full moon. Certainly such rituals were conducted at other times, yet in Vaegis we noticed or heard the rumble of bubin at moonlit nights. The moon brought light into the long and dark northern night and I was frequently outside at such times.

A drum is an indispensable aid for a shaman. It is used to invoke benevolent spirits. When travelling in the higher realms or in the 
underworld, it serves as a shield, even as protection against the arrows of aggressive spirits. A shaman needs to use aids to make a trip, for example, it takes hallucinogenic substances to carry out rituals and change the state of consciousness. Chukchi shamans used fly agaric (Amanita muscaria) to induce hallucinations. The spirit in the mushroom is a helper to the shaman and so he can enter the realm of spirits. Evil spirits need to be kept under control, but the benevolent ones to be turned to for help. When returning from the other realm, the shaman has usually accomplished his mission: found the cause of a disease or an enemy and gathered information about questions that interested him, all of which he will now put to use.

V. Bogoraz-Tan marks that here and there Chukchis sacrificed to the new moon each month. This sacrifice included blood soup, meat, fat and reindeer figurines made of crushed tree leaves. Reindeer were rarely slaughtered, only in the cold season.

One evening bubin beats were heard from a lonely yaranga nearby Vaegi village. We happened to be out at the time looking at the aurora borealis and asked locals what the beat meant. We were answered that the shaman is healing somebody. We asked girls to take us there to have a look. The girls agreed.

Having raised the skin covering the entrance of the yaranga, we saw someone lying on the floor in the firelight. On the other side of the fire the shaman was jumping up and down and playing the bubin. He was in ecstasy and did not notice us entering. Time and again he performed meter-high jumps in the air, at the same time beating the drum with a reindeer calf's shinbone. Someone was lying motionless in front of the fire. Some people were sitting at the back wall.

When Nina asked whether we could sit beside the fire, the shaman stopped the ritual and a terrible and shrieking flood of Chukchi-language invectives befell us. The shaman must have said something dreadful for the girls were petrified and then fled, dragging us along by the sleeves.

What the girls were told remained secret because all our later requests to see the shaman were firmly refused. Nobody told us what the shaman had said.

Later, back in Estonia, I read Bogoraz-Tan's book, who writes: "Chukchi shamans are exceptionally cautious when it comes to 
showing their rituals to foreigners. They are especially anxious at the start of their shamanship. However, even shamans with extraordinary powers refuse to demonstrate their art to foreigners. They consent only after repeated requests and even then they do not reveal the true extent of their powers and abilities.

They are afraid of other people whom they are not familiar with. Shamans are afraid of the bubins of aliens and their guardian spirits that could hide in their bags, as well as of "spirits" and "souls" which circle and hover around aliens. The most insignificant intervention by aliens or a mere doubt that they might do that ends a shaman's performance. (Siimets 1999: 147)

Browsing the journal I found yet another description from March 1971. This time the healer was not a shaman, in this case a woman, but a man from among reindeer herders. He had taken a vacation and travelled to Vaeg.

This evening we were at a party organised by local girls. Music was playing, people drank vodka shots and danced. Next follows an excerpt from my journal.

Suddenly drum beats started to sound from a nearby house. We wondered what is going on. Lyuba said that a man who knows how to heal people lives in that house. It is a full moon today and thus a good time to heal people.

"Is he a shaman?"

"No, but from time to time he helps those who need help. There is someone in each herd who knows the art of healing."

"What has healing to do with a full moon?"

"They say it is easier to heal at such a time."

"Maybe we could go and see?"

"Let's go."

We put overcoats on and went to the door of the house. Girls started to knock on the door. I went around the corner and looked in through the window. There were no curtains drawn and I saw a man in national clothes with a bubin. Someone was lying on the bed. The girls were still knocking on the door. The man stopped beating the drum and asked something. The girls answered in Chukchi and quickly explained something. We understood only the words etteki (in Chukch "hello") and ianki. I saw the man's angry face and through the window heard him railing. At any 
rate, we were not let in and the girls said that the neighbour is not in a good mood. We went back to the party.

I took some interest in healing and asked Lyuba whether she can tell me some magic spells that can be used to heal people. She said that such spells are usually received as an inheritance from forefathers. Her grandfather and grandmother died in the war with the Russians in 1950 and therefore could not pass incantations to her mother and father. Many elderly people survived among reindeer herders for they were the passers-on of ancient knowledge. Lots of herders know some kind of spells, but these are accompanied by unknown magic words or utterances. Incantations have no effect without the latter. These words have no meaning. The words are known only by a few people, the so-called sages. There are such sages in each reindeer herd and the neighbour was one of them.

Later, when I worked as a reindeer herder I spent a lot of time with Ejgeli, who was the shaman-sage of our herd. He told me that many spells mention the Sun, Moon, Milky Way, Morning Star and various constellations. Ejgeli sincerely believed that it is possible to kill your enemies by means of spells. That is why only shamans know such spells and keep them strictly secret. For example, when you kill a reindeer in a full moon, turn to the Moon with the right words, cut off the reindeer's head, put it on a pole, again say the right words, turning to the Moon for help, add appropriate utterances and force the pole with the head into the ground, your enemy whom you cursed will be paralysed for the rest of his life. Ejgeli also said that he will not tell me words because maybe I will do something foolish. It is believed that when someone uses spells improperly and unfairly, the person himself will be punished. However, when the enemy's guardian spirits are stronger than those of the one casting the spell, the latter is in trouble. If the enemy knows the spell also, the curse affects the one who said it first.

Such beliefs that it is possible to kill by means of spells or witchcraft are common all over the world. Only recently the TV programme Pealtnägija 'Witness' on ETV showed a clip from New Zealand where people were killed just on the assumption that they were witches. The killing of a witch by the relatives of the one bewitched was approved even by the relatives of the supposed witch. 
In Oceania the so-called lovers of the Elema people embody the paparet 'the Moon' who during mythic times draws women like a magnet. Men call themselves Marai which is the secret name of the moon, hoping to make the opposite sex as irresistible as they can be (McKenzie \& Prime \& George \& Dunning 2001: 146).

Next I will tell of a sacrificial ritual performed by Chukchi reindeer herders in a full moon.

August arrived. In the course of summer the horns of reindeer had grown big, but were still covered with skin and hair.

In the tundra mushrooms had already popped out of the ground a week before. The appearance of the first mushrooms excited the reindeer herd. They craned their necks and looked upwind into the distance. As soon as animals were released, leading reindeer made a dash for mushrooms. Others followed them quickly. The herd split as soldiers in a war. In a moment more than 4,200 animals were scattered all over the tundra. Every animal tried to find a mushroom. Having found one, it ran sniffing for the next one. Having got yet another one, it picked it up with the mouth and rushed for the next one. Reindeer had run as far as the eye could see.

I was with the Chukchi herder Ejgeli helping to drive slower animals closer to the first ones, leading reindeer. It was a hard job for reindeer were crazy and did not follow orders. Thanks to the swiftness of a herding husky we managed to gather the herd together at last. When the herd was released, everything repeated.

The closer to the end of August, the more mushrooms emerged from moss. Here and there entire mushroom circles appeared which on the ground looked like the Olympic rings. Such an abundance of mushrooms calmed the herd down.

The majority of mushrooms were boletuses. There were also other species, but in lesser numbers. I asked Ejgeli why Chukchis do not pick mushrooms for they are so delicious. Ejgeli looked me in the face and said: "At times you speak such nonsense as a stupid tanyg". Can't you see what these mushrooms do to reindeer? Animals go stark mad even if they smell mushrooms. Do you want to go crazy 
like them? Go on, crawl on all fours and eat them until your belly is swollen. Then you will see what happens."

"But where I come from we eat boletuses and russulas. We even have a song about boletuses, which says that boletuses fried with butter are excellent with vodka. I like especially chanterelles," I said.

"See, you yourself are saying that mushrooms are good with vodka. Can you get any vodka here? At home you eat mushrooms with vodka and don't even know that it is mushrooms that make you go crazy. Later you think that you drank too much vodka and that is why you were off your head."

The Chukchi became thoughtful and answered: "We pick and honour only fly agaric. These mushrooms are very strong. When growing, they can even break tree roots. Certainly there are other mushrooms that do that, but the real power of fly agaric lies in the fact that it can take you to the other realm. Of course, it depends on you - how well you can coax them. But bear in mind that you never eat an even number of mushrooms."

"It is said that when you eat two mushrooms, three spirits meet in you - yours and two of the fly agaric. If one of them is on your side, nothing bad happens. But when two of them turn against you, they take your spirit with them. They might not let your spirit go back to your body and then you will be dead. When you eat three fly agarics for the start, then at least one of the spirits is on your side and their powers are balanced, which means that everything is up to you. A person who eats a fly agaric might even see the spirit of it. The spirit can take you by hand and lead you to the underworld where you can meet your ancestors. Shamans use fly agaric to find souls that have been stolen by ketljas. The elderly speak about the fly agaric people. These are human beings who have one arm and one leg. They can be of immense help."

We left the matter at that. In the evening when I gathered the herd I saw a reindeer rubbing its skin-covered horns against a willow. When rubbed, the skin came off the horns. The skin revealed red bloody horns from which dangled few skin straps. 
In the evening when I sat at the fire and watched meat boil in a pot, I said to Vatap that a big male reindeer rubbed the skin off its horns. Ejgeli had gone somewhere and it was Vatap's turn to cook supper for men. Vatap looked at me, a strange expression on his face and shouted in Chukchi to other men to come to him. After Ejgeli had returned to the fire, herdsmen started to quietly and privately discuss something. Afterwards Ejgeli came to me and said:

"We'll be briefly away with the herd. In the meanwhile you rest here. We'll leave you here with the tent. We'll be back in three-four days. You have your rifle and cartridges, go hunting. Behind that mountain bighorn sheep are frequently found. Maybe you can catch one and make a nice meal out of it. By now they are quite fat."

I got the gist of the conversation and answered: "I travel with you people, sleep with you, eat the same food, drink the same water and breathe the same air as you. I have the same clothes. The only difference is that yours are made of leather and mine of canvas, but that does not matter. What I want to say is that I live with you and I am a herder just like you - that means a Chukchi like you. I think that the ketlja wouldn't be displeased by me coming with you."

Ejgeli didn't say a word. He went to other herders. They discussed the matter between themselves. Before long Ejgeli came back and said: "Ok, you can come with us, if that is what you really want."

Of course I wanted to go with them.

We travelled two days in a certain direction.

\section{A SACRIFICE TO THE KETLJA}

In the evening of August 9 a full moon started to slowly climb from between the mountains. Herders caught a very strong and goodlooking male reindeer with a chaad. The animal was black and had only lately removed the skin from his horns. The animal was pulled by a chaad to the top of a nearby mountain. The reindeer skipped and jumped on the rope. The animal was quite strong so that several men had to hold it back. At last we reached the top of the mountain and began to wait. Ejgeli had turned his face to the valley be- 
neath us and sang something in Chukchi. In between stanzas ringed the familiar monotonous "Eeeee, aaaaa, ooooo, uuuuu..."

Then he slowly took the ritual dagger from its sheath. Men pulled the chaad tight. Meanwhile the reindeer had calmed down, but now it started skipping again. Men held the animal on a tight rope. It became exhausted and stood still. But it was still reluctant, digging all four hooves strongly into the ground. Its body was at a backward slant as is usual in case of reluctant animals. Its eyes were bulging and it goggled at the preparations of nearby herders.

Ejgeli stepped closer. The reindeer, sensing danger, again started to skip on the rope, but not for long. Soon it stood stiffly, legs at a forward slant to resist the chaad's pull. That was the moment herders were waiting for. In such a position it was easiest to stab the animal to the left side, directly through the heart with a knife or spear. Ejgeli did that, delivering a strong stab to the reindeer's chest, right behind the front leg and pulling the spear out again. Blood gushed instantly from the wound. The reindeer started to skip and prance wildly. Herders strengthened their hold on the chaad. First the animal sank to its knees and then dropped on one side.

"Everything has gone really well," Ejgeli said. He meant that the animal had dropped on its right side. This meant that the chosen animal was acceptable to the ketlja. If the animal had dropped to its left side, blood would have poured out of its chest. Then a new animal would have been chosen and sacrificed. The procedure would have gone on until they found a sacrifice pleasing to the ketlja.

The reindeer's head was placed in the direction of the mountain over the valley. The animal was skinned right by the fire. Its guts were taken out. Its eyes were cut out of the skull with a sharp knife. The skull itself was chopped in half lengthwise and larger-thanusual skull pieces were left with the horns.

All that took place in complete silence, without any words spoken. The only sound was the men shuffling around. It is one of the Chukchi customs that it is forbidden to laugh or whistle while skinning an animal and it is best to keep silent. 
Ejgeli took a handful of blood from the reindeer's chest. He smeared its horns with it and placed them on the ground, tops down so that the skull formed something of a bowl. He also put some blood in the makeshift bowl. The reindeer's one eye was put into the blood. A piece of its liver, kidney, heart, lung and meat from its leg were also added. Next he took the offering and went down to the valley.

The full moon had risen high and the surroundings that before were in complete darkness were now clearly moonlit. I took interest in what the herders did and then directed my gaze to Ejgeli. All at once I noticed that moonlight that illuminated the mountainside opposite me created a weird sight. At a certain angle the shadows of bushes and rocks created by moonlight formed an image of a human head on the opposite mountainside. The man's head had eyes, a nose, mouth, moustache and beard and it looked down to the valley. Ejgeli was quite far, but still I could see how he bowed down at the foot of the mountain and put the offering on to the ground. His singing could be heard at the fire: "Eeeee, aaaaa, uuuu, ooooo..."

Men sat at the fire, legs crossed and rocked back and forth to the rhythm of the murmur. Years later when I told about my experience to Vigala Sass, he said that such singing (repeating vowels) has an effect on the solar plexus. Singing in such a way, murmuring inwardly and rocking to oneself gives a sense of pleasure and liberation. In general, people can be influenced with rhythm and sound. Charms and spells accompanied by rhythm have a stronger effect. Vigala Sass claims that he has conducted experiments that the vibration of drum beats during a ritual gives ions a positive charge neutrons gain charge and turn into cations. The phenomenon is especially distinct at sites of ritual activity where nature is said to thrive. The same can be achieved by means of singing.

The effect is made use of at religious and public events: in churches, chapels, song festivals, nightclubs and dance clubs. But in essence it is hypnosis and autosuggestion in its purest form.

When Ejgeli came back, he put the meat to boil in a pot. He cut the other eye out of the skull and cut in half on his palm. Liquid oozed out of the eye into the hollow of his hand. At first he drank the liquid and then ate the rest of the eye. He was the main character of this ritual - the performer. Eyes are given only to the most impor- 
Figure 1. The Chukchi conception of the sky. After Vladimir Bogoraz-Tan.

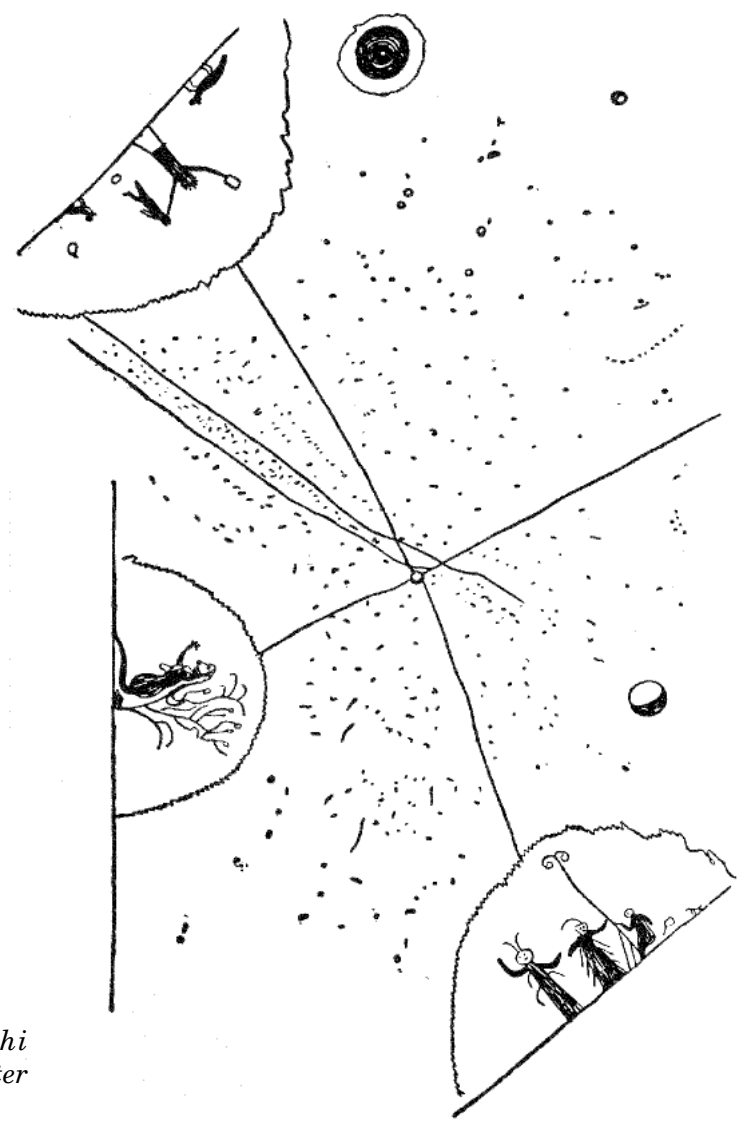

tant guests. This time there were two of them: the ketlja (the spirit) and the shaman.

In a little while partly bloody meat was taken from the pot and men started to eat it. When the meat was finished, more of it was boiled. Later blood was taken from the reindeer's chest by handfuls and added to the meat soup. Veem took some roots from his backpack which were later added to the boiled blood. When the blood did not stick to a bone spoon any more, the pot was removed from the fire and placed in the middle of the circle. Every man took a short-handled bone spoon from his belt. In turn they took the blood soup with 
it and blowing on the hot liquid, started to eat it. In a long time they ate as much as they could. Veem and Vatap went to the herd to replace the men so that they could come too and join the feast. It was around three o'clock when everyone went to the tent to sleep.

In the morning when the sun rose, it could be seen that there were lots and lots of horns at the foot of the opposite mountain. In some places they had been piled into heaps, forming round horn stacks. The sacrifice had been thankfully received for the horns at the foot of the mountain were on their side and offerings had disappeared.

It could be guessed, watching the heaps or horns, that the sacrificial site had been used by Chukchi herders for decades. Such a heap of horns is called a tönmaj. They can be found at burial sites and other sacrificial sites.

The sacrificed reindeer is usually eaten completely but this time the rest of it was dragged from the place of killing down to the foot of the mountain and left there. The bones of previous sacrificial animals were already waiting there. Bones could be seen under a number of bushes. The desolate place was left in silence.

\section{THE EARTH AND THE ESTONIAN STAR BRIDE}

According to a Chukchi legend the Earth (Nutenut) lives in a large house of iron. The story tells that the Sun, Moon, Sky, Sea, Dawn, Mist and the Universe were visiting him. They all wanted to marry the Earth's beautiful daughter. The story resembles to some extent the Estonian myth of the Star Bride yet their endings are different. In The Star Bride the maiden picks the Star to be her fiancé. In the Chukchi myth the maiden does not get to choose a fiancé, but suitors compete and the winner marries the bride. However, none of the aforementioned suitors wins the contest, but a Chukchi shaman Jettögöt, who raises his staff and touches every rival with it. As a consequence the touched side of each suitor catches fire and they all flee in panic. And Jettögöt marries the girl.

By the way, polygamy is not forbidden among Chukchis and is unofficially practiced to our day. As can be seen from the above text, the Sun already has a wife called Kavra-nya. 
Stars and constellations are among the prominent beings listed above (vabrgbt).

\section{THE NORTH STAR}

The North Star (in the Chukchi language Iluk-eyer 'the Immobile Star', Olqep-ener 'the Nail Star' or Unp-eyer 'the Driven-in Stake Star,' 'Pole Star') is cast in the central role among stars. V. BogorazTan claims that the latter version of the star's name is common all over Europe. The North Star in the firmament is like a pole or stake driven into the ground around which stars circle, resembling horses or reindeer tied to a pole. Its house is near the Zenith and through its smoke opening it is possible to travel between worlds. Due to that opening the North Star can be seen in all worlds, in the underworld as well as in upper realms, while other stars and constellations are not the same in different realms. At the same time it is believed that the North Star's house is higher up than other houses. Its house is made of ice-like substance and to its top is fixed a lighthouse-like source of light (Bogoraz-Tan 1939: 23).

In his book Andres Kuperjanov lists the names different peoples call the North Star by the Golden Pillar (Mongols, Buriats, Kalmyks and Altaian Tatars), the Iron Pillar (Kyrgyzes, Bashkirs and Siberian Tatars), the Lonely Stake (Teleuts), the Golden Stake (Tunguses) (Kuperjanov 2003: 143). All these ethnic groups picture the North Star as an immobile stake or pillar or a stake driven into the sky. The same applies to Chukchis. The Chukchi name of the Nail Star has a close resemblance to the Estonian name of Põhjanael 'Northern Nail'.

\section{ARCTURUS AND VEGA}

In the Chukchi worldview stars ranking next to the North Star as to their importance are the so-called heads (in Chukchi Leutti). Heads are formed of two stars. The First Head is Arcturus in the constellation Bear Watcher (Chukchi Janotlaut, Estonian Karuvalvur 'Guardian of Bear') and the Second Head is Vega in the constellation Lyra (Chukchi Jaatlaut, Estonian Vabamees 'Freeman', 
Voorimees 'Coachman'). According to Chukchis these stars are brothers or cousins.

Travelling in the nighttime tundra Chukchis use the mutual position of the heads and the North Star as a reference point to find the right direction. Arcturus is sometimes also called the leader or the guide of stars (Bogoraz-Tan 1939: 24).

Chukchis turn to both of the stars to seek help when healing. In case of diseases a sacrifice has to be brought to Arcturus or the First Head. In case of stomach ache the sacrifice and spell have to be addressed to Vega or the Second Head.

\section{STAFF STARS, ORION AND OTHER CELESTIAL BODIES}

The Estonian Staff stars are the three stars in a row in the constellations Aquila (Old Staff Stars) and Orion (New Staff Stars) (Kuperjanov 2003: 177).

The stars $\alpha$ (Altair) and $\gamma$ (Tarazed) in the constellation Aquila have a special meaning to Chukchis. They are called by the name Pettigъn. The Aquila constellation brings the new year to Chukchis for it appears for the first time on the horizon on the winter solstice. Reindeer herders as well as Chukchis living in the coastal areas brought sacrifices on the occasion, at least formerly. Especially suitable sacrifices were fat male reindeer. At other festivals blood is sometimes sacrificed and reindeer are exchanged for symbolic statues made of plants or snow (Bogoraz-Tan 1939: 75).

V. Bogoraz-Tan heard in Anadyr as well as Kolyma that Pettigún had once been a chieftain who was lifted to the sky. Unfortunately he had no chance to gather more data about the subject (BogorazTan 1939: 24).

Other constellations are not considered to be prominent beings (vaъrgъt) by Chukchis. V. Bogoraz-Tan has listed the most important ones.

Chukchis call Orion Rultennin 'Humpback'. It is the humpbacked archer. The star $\lambda$ of Orion is its head, $\alpha$ and $\gamma$ shoulders, $\kappa$ and $\beta$ 
legs. Orion's belt forms the Humpback's hunched back. The two large stars below the belt are the Humpback's genitals.

Chukchis call the constellation Leo Vetcayaut 'Standing Woman'. Women participating in folk dances are usually called by that name. In folklore Standing Woman is believed to be the Humpback's wife, who sleeps on bare ground. She was so jealous over Orion who lusted after the Pleiades that he hit Humpback with a cutting board. The blow was so strong that it injured her husband's back. That is why he has a hunched back. After the fight Orion drove his wife away and up to this day she is forced to sleep in the mid-sky.

The constellation Leo consists of seven stars. The star $\varepsilon$ is her head, $\eta$ shoulders, Regulus her knee, the tiny star between $\varepsilon$ and $\eta$ is a pillow she rests her head on while sleeping, and other stars form the contour of her body.

The Chukchi name of the Pleiades is Nausqatiomk nn 'Group of Women'. These are six single girls waiting for their men. After having been crippled and driving his wife away Humpback tried to marry whichever one of them, but all the girls disdained him for his too big phallus. The obtrusive suitor took a bow and started to shoot the frightened girls who fled from the shooting range of his bow. The main star of the constellation Taurus is a copper-tipped arrow shot by Orion. It is called accordingly in Chukchi mythology -Celgъmaq $\mathbf{}$ ' 'Copper Arrow'. The arrow did not fly as far as the fleeing girls and fell into some moss. The humpback's bow is an arched, bow-like star cluster between Orion and Aldebaran. A version of the same myth by Kolyman Chukchis tells that the Group of Women standing coolly in a distance are protecting themselves with nets. The net is formed by numerous tiny stars into which the Copper Arrow has been caught (Bogoraz-Tan 1939: 25).

In Greek mythology Orion was a wild and mighty hunter from Boeotia who pursued the Pleiades. In case of many Siberian peoples the constellation Orion is associated with hunting. In Estonian folklore it is the household tools of celestial beings that are scattered in the heavens. In southern Estonia Orion is called Flail and Rake, also in Lahemaa and Saaremaa the constellation is associated with threshing, but is called after a threshing stick Vart or Vart stars (Kuperjanov 2003: 165). 
Pleiades is due to its compactness and peculiarity known everywhere it can be seen. Pleiades has usually been seen as a group of people (mainly of girls), seeds, chickens or a nest. In classical astronomy each of Pleiades's nine stars has its own name: these are Atlas and oceanic nymph Pleione and their seven daughters Alcyone, Maia, Asterope, Taygeta, Celaeno, Electra and Merope, whom Zeus lifted to the heavens when they were fleeing from Orion who wanted to marry Merope (Kuperjanov 2003: 183). It is interesting to note that the classical version has a close resemblance to the Chukchi myth of Orion and the Pleiades.

According to Chukchi mythology the star $\alpha$ of the constellation Auriga or Capella is a male reindeer who has been harnessed to a human being's $(\varepsilon)$ sledge drawn by two reindeer. All the four stars are in Chukchi called Съmya-Nletel ъn 'Guided Steers'. The star $\beta$ is a leather collar that has been lost by others who were travelling with reindeer and have turned back to look for it. A spare male reindeer $\delta$ tied to the sledge and running next to it is also included in the constellation. From the other side a fox is approaching the collar (Bogoraz-Tan 1939: 25).

The material gathered by Jakob Hurt reveals the Estonian belief that Capella was the original Christmas Star which in ancient times signalled the birth of Christ and guided the wise men from the East to Bethlehem (Kuperjanov 2003: 163).

Ursa Major is a well-known constellation as in all regions it is visible. With Orion they form so clearly defined constellations that it is impossible to think that they might have a different shape. The Estonian equivalent for Ursa Major is Suur Vanker 'Great Wagon' and in many English-speaking countries the constellation is called Big Dipper. For Tatars Ursa Major is an omen of doomsday. For them the constellation consists of seven dogs and when they flee, doomsday arrives.

In Germanic beliefs Ursa Major represented Odin and later Charlemagne's wagon. In China the constellation is called Emperor's Wagon (Kuperjanov 2003: 180-182).

Yet for Chukchis Ursa Major does not form an integral constellation. Six of its stars are called Wъjotkъnaulъt 'Sling-Throwers'. The 
seventh star, which actually is a pair of stars, is a fox that is gnawing discarded reindeer horns.

The constellation Gemini, the twins Castor and Pollux, are two reindeer fleeing from two hunters. Either hunter drives a reindeer team. One of the men has tied a dog to the sledge. Chukchis call the constellation Gopka-velerkъlelıt 'Hunters with Reindeer'. Hunters are represented by the stars $\gamma$ and $\chi$, and $\lambda$ and $\eta$ from the neighbouring constellation.

Chukchis call Northern Crown (Corona Borealis) 'White Bear's Paw'. The constellation Delphinus is called 'Seal': the star $\varepsilon$ is its head and the other four are its flippers. Chukchis call the Milky Way Cigej-veem 'River of Sand' which flows eastward. There are many islands in the river (Bogoraz-Tan 1939: 25).

In an ancient Egyptian myth the god-creator Atum appears from the primeval ocean Nun. Of its seed, or unity, he created duality which is represented by the twins Shu, the god of light and evening, and the lioness Hathor-Tefnut, who embodies the Sun. The couple begat Nut, the sky, and Geb, the earth. Nut was represented by a woman whose toes and fingers touch the earth, her body forming the sphere of heaven. Stars on her body are the Milky Way. Geb and Nut in turn begat the gods of the so-called Osiris-cycle. The eldest son, Osiris, inherited kingship from Geb. Osiris was accompanied by his sister Isis who at first could have been the symbol of kingship. Isis also symbolised Sirius. Set killed Osiris in a quarrel over the kingship of Geb, chopped up the body and scattered its pieces all over Egypt. Based on that myth numerous centers of the cult of Osiris sprang up and all had allegedly a piece of the body of some god for a relic. After Osiris was murdered, his two sisters Isis and Nephthys travelled around gathering the pieces of Osiris' body and putting them together. They even succeeded in reviving Osiris for a short time. The identification of Osiris with Orion which is not seen in the sky for around 70 days a year reflects the 70-day Egyptian mummification ritual. Isis floated over Osiris' aroused penis and conceived. She gave birth to Horus. Isis was forced to hide Horus in rushes from Set. She was helped by Uto or Uadzit (English 'fresh, green') and the vulture Nehbet from $\mathrm{Al} \mathrm{Kab,} \mathrm{who} \mathrm{both} \mathrm{represented}$ one of the two most important crowns (McKenzie \& Prime \& George \& Dunning 2001: 35-37). 
According to Chukchis the five stars of the Cassiopeia constellation are five reindeer standing in the middle of a river.

Chukchis call comets smoking stars. The word "smoking" refers to the Chukchi belief that comets are some kind of creatures who cook all the time.

Planets are called "stars that have crooked paths" which is due to their seemingly incorrect trajectory in the sky.

The Morning Star or Venus is called Gъto-tlap. The first part of the name means in Chukchi "big, strong." The other part Chukchis were not able to explain, but it has probably something to do with the Koriakian word lelapъcan, which refers to a star and is in turn derived from the verb lelapeksn 'to look'. In that case the name of Venus would be the 'Great Star' or 'Great Eye'.

Venus, which is seen in the morning, is called Kerg-ayatlın'sn 'the Bright Star'. Chukchis tell that Venus is mъk-evirъnlın 'has several robes' which means that the star shines differently at different times (Bogoraz-Tan 1939: 29).

The Sumerian myth of seasons is connected to the Morning Star. The Akkadian moon-goddess Sin (Sumerian Nanna) had a daughter called Ishtar (Sumerian Inanna). She is associated with the planet Venus. She was the goddess of love and sex who was well-known as to her insatiable and restless nature. Of Ishtar's many lovers the most prominent one was Dumuzi (later Tammuz), the god of fertility and vegetation. The goddess Ishtar left for the underworld to visit her sister. She passed seven gates each of which ripped off one of her garments. So when she met her sister Ereshkigal she was stark naked. She fell ill and the earth ceased to yield fruit. Ea, the goddess of water and witchcraft, tried to save Ishtar, but with no success. Then Ereshkigil had mercy upon her sister and let her return to the earthly realm. Having returned, Ishtar found all her servants mourning. Only her lover Dumuzi was having the time of his life. For punishment Ishtar sends Dumuzi to the underworld for a certain period of time each year (McKenzie \& Prime \& George \& Dunning 2001: 25).

In ancient Egypt Horus was the king of the gods and the ruling pharaoh was believed to be his incarnation. Horus' falcon head and 
double crown depict him on the one hand as the god of the sky, relative of $\mathrm{Ra}$ and the embodiment of the Morning Star, but on the other hand refer to his royal functions (McKenzie \& Prime \& George \& Dunning 2001: 35).

Chukchis sacrifice to the Morning Star in many cases. After the autumnal sacrificial rites of young reindeer the next important day is putting up the winter-yaranaga. I have not taken part in that sacrifice for I returned to Estonia at the beginning of October. As described by V. Bogoraz-Tan, at that time two reindeer are sacrificed to the Morning Star and one to the earth. I have also written earlier of the offering Chukchis bring to the Morning Star to win their beloved's heart (Siimets 2003). Next follows an excerpt of the story.

When a Chukchi herder falls in love with a Chukchi girl, who pays no attention to him and doesn't want to marry him, he has to hide near or behind her yaranga. In a word, the girl must not see him. When the girl takes a pee, the herder goes to the blotch of urine on snow after the girl has left. There he must say the following words:

"It was not pee that dropped here. These were your heart, liver and kidneys that dropped here."

Now the herder has to wait until the Morning Star rises. He has to bring an offering to the Morning Star. A small-scale offering, for example, a puppy, will be enough. Of course, a rich man can sacrifice a reindeer calf or a reindeer. When the offering has been brought, the herder asks the Morning Star to give him ironclad boots that have sharp nails underneath. Then he goes back to the puddle of pee and starts to stomp his feet on it. At the same time he repeats these words over and over again. (Siimets 2003: 231)

The ritual has to be conducted seven times and the girl will be in love with you forever.

The Morning Star can also be used to bring your darling back from the underworld. For that end the dead one has to be placed on a bed of reindeer skins in the sleeping polog 'a sleeping tent inside the yaranga' and the one conducting the ritual has to go out to the tundra in the direction of the Morning Star. Then a puppy has to be sacrificed to the Superior Being and the Morning Star and a series 
of procedures has to be carried out, for example, blowing into the dead one's ear and barking like a dog. The latter dispels the ketlja who has taken the dead one's soul and so the soul can return to its body.

In order to heal a sick organ, a sacrifice has to be brought to the Morning Star in the early morning.

Chukchi hunters celebrate a special festival so the hunt for wild reindeer will be successful. In the morning of that festival a reindeer is sacrificed in the honour of a wild male reindeer and the other to the Morning Star. Sometimes a third sacrifice is brought to Nadir. The horns of a wild reindeer shot earlier are decorated with the intestines and blood sausages made of the killed animal. A rich blood soup is made and meat is boiled. Sacrifices are brought to all guardian and home spirits. Later a young reindeer is killed and its blood is used to smear reindeer horns. During the festival the heads of sacrificed reindeer are brought to the yaranaga and hung over the fire on a prop. Afterwards these are taken to the graves of ancestors (Bogoraz-Tan 1939: 81).

If a wild reindeer comes to your yaranga and you want to domesticate it, you have to turn to the spirit of Zenith or to the spirit of a superior being who lives there. The same applies when you want to get rid of bad weather.

\section{SUMMMARY}

For their entire lives people have to make choices. The quality of their lives depends on these choices. The same applies to Chukchis. Oftentimes conquerors introduce their own beliefs and religions, for example, Christianity in Estonia. This brings along new visions, legends and myths, of which some are also related to the firmament. Chukchis are probably the only nation in the territory of the former czarist Russia and the Soviet Union who have in general retained their animalistic religion. It is a historical fact that the Chukchi land is the only territory of czarist Russia that gained real autonomy and that was not completely conquered by Russians.

According to a paragraph in the Russian code of laws the Chukchi land is called Russkaia ne vpolne pokorennaia territoria 'a region not completely subdued by Russia' and local laws applied there. 
The territory west of the Anadyr and Chauna rivers was called Chukchi Land. The inhabitants of the territory, like all ordinary Chukchis, had certain privileges to decide matters, including murders and blood feud related to it, according to their old traditions. But only in case such a criminal incident occurred in the boundaries of their territory. Siberia was conquered very quickly. In 1586 the Tyumen castle was built on the ruins of Chingi-Turo, the capital of the realm of the khan Kutchum. In the following 62 years Cossacks from Tomsk reached the Sea of Okhotsk, but could not press on to the north. The lower reaches of the Kolyma River served for decades as a borderline. Chukchis took a fierce stand against the invaders. When the war had lasted for as long as the conquest of the whole of Siberia, Catherine II was forced to yield to the Senate's request and abandon the idea of conquering Chukchi Land. In 1771 Anadyr castle was destroyed and finally in 1778 peace was made which neither of the sides violated. An order was issued from St. Petersburg to make national coats of arms and send these to the Chukchis to be hung on trees on the coast and to be shown to people who disembark from ships as to announce that these lands belong to the Russian Empire.

The fact that nobody knew the exact extent of the Chukchi land and the size of its population certainly contributed to the former development. Chukchis did not exchange captives and all conquerors were killed. Hence nobody knew much about these people. Chukchis could not be brought to Christianisation in the czarist era or were completely assimilated in the Soviet time. We can only assume what goes on there now.

When I was in the Chukchi land, bringing sacrifices was a part of the everyday life of the reindeer herding team to dispel evil spirits and attract good ones.

The firmament of the Chukchi world view is related to their main source of subsistence - reindeer herding. In many cases it is the names of reindeer or their herders or hunters that stars are called by. There are myths about constellations the original sources of which can be traced back to the migration route of humans through Eurasia or even to the common homeland of yet earlier times. 
Certainly Chukchi beliefs would be of great help when interpreting the background of Estonian nature-worship. Such mythologies and beliefs should be studied before it is too late, for the Chukchis are a nation on the verge of extinction and their culture will be lost forever with them.

\section{Comment}

1 Tanygtan means 'stranger', 'enemy' in the Koriaki language. Probably the word has the same meaning in Chukchi (Bogoraz-Tan 1934: 3). In 1971 a shorter word tanyg was used to refer to foreigners, especially to Russians or as an invective. We were also called tanygs when we first arrived, but later they called us by the name ianki. According to BogorazTan (1934: 8), tanyg means 'a Russian'.

\section{References}

Bogoraz-Tan, Vladimir 1934. Chukchi [The Chukchis], I. Leningrad: Izdatelstvo glavsevmorputi.

Bogoraz-Tan, Vladimir 1939. Chukchi [The Chukchis], II. Leningrad: Izdatelstvo glavsevmorputi.

Kulmar, Tarmo 2004. Inti Raymi ehk päikesepüha - Kolumbuse-eelse Peruu inkade suurimaid usupühi [Inti Raymi or the Sun Holiday - One of the Greatest Religious Holidays of Pre-Columbian Peruvian Incas]. Mäetagused: Hüperajakiri, 24, pp. 81-90. http://haldjas.folklore.ee/tagused/ nr24/kulmar.pdf [In German: Das Sonnenfest Inti Raymi als ein Höhepunkt des religiösen Jahres in der Inka-Religion. Mitteilungen für Anthropologie und Religionsgeschichte (MARG), 15, 2000: Religiöses Reisen. Ugarit-Verlag, Münster, 2003, pp. 51-60.]

Kuperjanov, Andres 2003. Eesti taevas: Uskumusi ja tôlgendusi [Estonian Sky: Beliefs and Interpretations]. Tartu: EFI.

McKenzie, Michael \& Prime, Richard \& George, Lisa \& Dunning, Ray 2001. Mythologies of the World: The Illustrated Guide to Mythological Beliefs \& Customs. 2001. New York: Checkmark Books.

Ó hÓgáin, Daíthí 2004. Kujund kui narratiivi allikas iiri rahvajuttudes [Image as the Source of Narratives in Irish Folk Tales]. Mäetagused: Hüperajakiri, 24, pp. 151-169. http://haldjas.folklore.ee/tagused/ nr24/iirijutt.pdf

Siimets, Ülo 1999. Tšuktšid II [The Chukchis II]. Mäetagused: Hüperajakiri 12, pp. 130-137. http://www.folklore.ee/tagused/nr12/tsukts.htm

Siimets, Ülo 2003. Tšuktšimaa legendid [Legends of the Land of the Chukchi]. Mäetagused: Hüperajakiri, 21, pp. 231-245. http://www.folklore. ee/tagused/nr21/legendid.pdf 